\title{
Academic Dishonesty Among Higher Education Students: The Malaysian Evidence (2014 To 2016)
}

\author{
Ramlan Mustapha (PhD) \\ Zaharah Hussin (PhD) \\ Saedah Siraj $(\mathrm{PhD})$ \\ Ghazali Darusalam (PhD)
}

\begin{abstract}
Academic dishonesty has become a global issue and this threatens the academic world from time to time, as listed in findings worldwide. This study aims to provide some insight into the activities of academic dishonesty among higher education students in four selected Malaysian public universities. A survey was conducted on 453 Muslim students in 2014, 365 students in 2015 and 320 students in 2016. The data analyzed using SPSS version 20 to detect validity and reliability of findings. The result shows that $47 \%$ of students had committed academic dishonesty at least once in 2014; this was prevalent in 51\% of students in 2015 and $49 \%$ in 2016. Analysis also indicates that the dominant aspects of academic dishonesty include plagiarizing references while completing assignments and accessing information through digital resources. These outcomes could be used by stakeholders and academic institutions to raise the ethical awareness of plagiarism and academic dishonesty among students pursuing further studies. Nonetheless, further research and academic practices are tentatively proposed.
\end{abstract}

Keyword: Academic Dishonesty, plagiarism, Muslim Students 


\section{Introduction}

The stability and credibility of educational institutions reflect an important aspect of a nation's educational development. Academic integrity is fundamental in strengthening a country's education system and society but issues involving academic dishonesty are currently growing and becoming cancerous, thereby damaging the integrity of the education system. Enormous implications will occur if this phenomenon is not given serious considerations. The outcome of these implications can affect institutions of higher learning, making it difficult for these institutions to achieve their academic goals in disseminating knowledge (Jurdi, Hage, \& Chow, 2011).

Academic dishonesty has become an increasing challenging issue among academic institutions (Teixeira \& Rocha, 2010). Studies such as those done by Jones (2011) found that majority of students commit academic dishonesty based on several factors with 92 percent of them doing it because they want to earn higher grades and 75 percent of them doing it because they were too busy with lessons and assignments. Willian, Nathanson and Paulhus (2010) reported that the percentage of academic dishonesty among students is approaching $100 \%$ as compared to previous years.

In comparison to the west, Asian countries are no exception. A study conducted by Lin and Wen (2007) in Taiwan showed the percentage of academic dishonesty to be at the level of 61.7 percent. Galloway (2014) studied 4316 high school students and found that almost 93percent of these students had committed academic dishonesty at least once in their studies. In New Zealand, nine out of ten students had engaged in academic dishonesty (May Wah et al., 2012) while Diekhoff, LeBeff, Shinohara and Yushukawa (2010) reported that 55.4 percent of students in Japan cheated in their exams. Linked to this is Peled and Grinautski (2013) who found that 10 percent of students had copied through the "cut and paste" method from the internet with 40 percent of these students using the same method to solve their project papers.

To drive the country towards higher rankings, higher education provided by institutions need to be more systematic and 
there must be integrity in academia so that the respective countries can be more competitive within the region. In developed countries, issues involving academic integrity is currently being debated and this issue must be taken seriously by all parties. For instance, plagiarism needs to be addressed and care must be taken so as not to compromise personal, community and institutional integrity, which can retard the development of higher education in the country. In the Malaysian education environment, academic dishonesty is an issue that is rampant and as such, it is being studied and researched by many researchers (Saveri \& Ebrahimi, 2012). Focussing on public universities, Nurshiha and Nurliyana (2013) found that 82 percent of students had committed academic dishonesty while Idzwan, Noor Rahmawati, Aslinda and Zulkarnain's (2013) study of 388 respondents from various faculties found that students from the Faculty of Information Technology committed the most academic dishonesty when compared to other faculties. Their academic dishonesty was eased by the access to ICT and its facilities in acquiring information readily.

This implies that the influence of the Internet and other new sources of electronic media-based teaching has a considerable impact on academic dishonesty. In other words, rapid development and the evolution of virtual resources can primarily affect the internet, thereby causing a huge problem for education today. Peled, Eshet and Grinautski (2013) hence conclude that the ability to access information without limits and its easy accessibility gives space to the mushrooming of academic dishonesty (Shu, 2012). There is evidence which shows the effect of the behavior of internetbased academic fraud. Based on the Center For Academic Integrity of Duke University's survey, Ma, Wan and Lu (2008) reported that 48 percent of the respondents believed that dishonesty involving internet is getting worse and more effective while 13 percent of them thought that academic dishonesty committed by students are related to the Internet.

With institutions aiming to achieve good rankings, it is necessary to conduct further research so as to curb these issues which can affect the reputation of higher institutions from spreading. Alternative measures must be taken so as to address this issue. This 
not only helps to preserve the reputation of institutions of higher learning in the country, it can also maintain the quality of the country's education system.

\section{Academic dishonesty and higher education}

Academic dishonesty is defined as any act involving dishonesty or dishonesty in academic works, whether imitating, buying assignments, or copying and printing the work of others without permission (Stuber, Wisely, \& Hoggart, 2009). Academic dishonesty has become a global concern. Every year a lot of research are conducted either by public institutions or private institutions of higher learning with a small degree of academic dishonesty occurring (Beck, 2014). While lecturers usually detain students caught cheating in the examinations, students providing mimic prints of information that are obtained from various sources in their written assignments may also be penalised (Barizah, Suhaiza, \& Suaniza, 2010). In their study, Demoera and Jindrova (2013) reported that The Center for Academic Integrity (CAI) had found that more than 75 percent of college students will commit higher education academic dishonesty at least once in their studies. A report from the Josephian Institute of Ethics in California found that 72 percent of students in higher education have confessed to academic dishonesty such as replicating in examinations and so on (Koul, 2012).

Current data show that the percentage of academic dishonesty is still above 70 percent among students in higher education (Whitley, 1998). In another study, McCabe and Trevino (2002) reported that academic dishonesty is increasing at an "Alarming rate". This is illustrated by the Faqua scandal which occurred at the Duke University's School of Business in 2007 which involved 34 graduates who were caught for committing academic dishonesty in groups (Briggs, Workman, \& York, 2013). Focussing on 321 samples taken from selected universities in Canada, Jurdi, Hae and Henry (2012), found that half of the students had been involved in at least one aspect of academic dishonesty.

As mentioned earlier, IT (Information Technology) such as the Internet, social networking sites and so on can be a threat to the 
academic world. Many studies (Peled, Eshet, \& Grinautski, 2013; Lau, Caracciolo, Roddenberry \& Scroggins, 2012) involving the use of ICT and its impact on academic dishonesty have been intensively conducted. It was reported that in 1999, as much as 10 percent of students were copying from Internet sources through "cut and paste" but by 2005, about 40 percent of the students were using the same method for their project papers. Around 1970, about 107 metaanalysis studies were conducted specifically to understand this phenomenon (Elliot, Deal, \& Hendrik, 2014). Among these, Whitley (1998) estimates that around 70.4 percent of students had performed academic dishonesty and Simkin and Mc Leod (2010) estimate that between 60 to 86 percent of the students were involved in academic dishonesty. In 2005, Donald McCabe made a very significant study covering 80,000 students. He found that about 21 percent of these students had commited serious academic dishonesty at least once. His study also showed that 68 percent admitted to doing tasks together and 63 percent had committed plagiarism (McCabe, 2005). In another study of 50,000 students, Harding, Carpenter and Finelli (2004) found that 28 percent of students had admitted to academic dishonesty during examinations. Linked to this is Josien and Broderick, (2013) who stated that 70 percent of the 50,000 undergraduates from 60 campuses worldwide, between 2002 to 2005, had also copied and committed academic dishonesty.

Based on the above discussions, it can be deduced that the problem of academic dishonesty tends to occur in most institutions of higher learning.

Aiming to make a comparison of the statistics on the range and level of academic dishonesty among students in higher education students in Malaysia between 2014-2016, this study focusses on data extracted from these three specific years. The research question formulated attempts to see if an alternative has been done to deal with these problems and if so, was it effective or not. This study also aims to fill the gap in current literature by attempting to compare the results of academic dishonesty of three years (2014-2016) among higher education students. 


\section{Significance of the study}

Current academic development implies that too many issues associated with academic dishonesty has a significant relationship with students. Studies conducted earlier also indicate that a very high proportion of academic dishonesty in Malaysia are committed by 82 percent of students (Norsiha \& Nurliyana, 2013). In addition, the report provided by the Center for Academic Integrity (1999) also showed that more than 70 percent of high school students were involved in academic dishonesty. These two reports strengthen the findings provided by Domeova and Jindrova (2013) who found that over 75 percent of high school students committed academic dishonesty. This issue, if not duly arrested and addressed, can be a very big issue that challenges the integrity and quality of an institution. In this regard, the outcome derived from the current study can be used by stakeholders and institutions of higher learning to raise a higher awareness of academic dishonesty and in that aspect, find more effective means of dealing with this issue.

This study specifically aims to identify the level of academic dishonesty among Malaysian higher education students between the years 2014 to 2016 and whether there is any significant difference in the level of academic dishonesty among Malaysian higher education students in Malaysia in the years between 2014 to 2016 ?

\section{Methodology}

This study is based on a survey which involves a questionnaire that was formulated for three years. It was adapted from the Academic Integrity survey sample items, the high school version (Mc Cabe, 2011) where 11 questions were adapted. Students were expected to take approximately 5 to 10 minutes to complete the questionnaire. All questionnaires were distributed and taken back after completion. The data obtained were then analyzed using IBM SPSS version 20. The respondents involved were undergraduate Muslim students who were recruited from selected public universities in Malaysia. The respondents consist of 435 students recruited in 2014, 365 recruited in 2015 and 320 student recruited in 2016. 


\section{Sampling}

Th sampling method was based on convenience sampling because the researchers did not obtain the sampling frame. Sekaran (2003), Malhotra (2010), and Sekaran and Bougie (2010) had confirmed that this method can be used to obtain an initial overview of the situation in conditions where the researcher is unable to obtain the sampling frame. Nonetheless, this method has also been criticized to be biased as it may not represent the general population. In the context of this study, samplings were recruited based on suitability and ease to get feedback. One advantage of this sampling is that they were homogenous and all were bachelor degree students studying in Malaysian institutions of higher learning.

\section{Reliability}

Reliability refers to the degree of conformity and confidence in the measurement of an instrument which should have the characteristics of stability, consistency, friendliness and accuracy (Kerlinger, 1986). This study uses the Cronbachs Alpha model to measure the Cronbach's alpha reliability or credibility of the Scale as illustrated by Table 1 .

Table 1: Reliability

\begin{tabular}{ccc}
\hline \multicolumn{3}{c}{ Cronbachs alpha } \\
\hline $\mathbf{2 0 1 4}$ & $\mathbf{2 0 1 5}$ & $\mathbf{2 0 1 6}$ \\
\hline$\alpha=.768$ & $\alpha=.803$ & $\alpha=.813$ \\
\hline
\end{tabular}

In this study, reliability was deployed to measure the accuracy of the data (goodness of data). According to Sekaran and Bougie (2010), reliability is used to measure the consistency of the developed instrument. The results of this study were also analysed through the Cronbach's alpha value for the entire item. For the year 2014, it was $\alpha=.768$ while for 2015, it was $\alpha=.803$ and for 2016, it was $\alpha=.813$. 
The reliability of the study meets its validity based on the degree of compliance and confidence in measurement tools that carried the characteristics of stability, consistency, friendliness and accuracy (Kerlinger, 1986). There are a variety of opinions to determine the reliability and value based on the review of literature. Nunally (1978) argues that the reliability needs to be more than 0.70 so as to determine internal consistency. Carmines and Zeller (1979) state that the reliability should be 0.70 or more. However, the new scale shows that the value of 0.60 can be considered and accepted (see Nunally \& Bernstein, 1994).

\section{Findings}

The demographic analysis is projected in Table 2.

Table 2. Demographic Analysis

\begin{tabular}{|c|c|c|c|c|c|}
\hline \multicolumn{2}{|c|}{2014} & \multicolumn{2}{|c|}{2015} & \multicolumn{2}{|c|}{2016} \\
\hline Sex & $\begin{array}{l}\text { Percent } \\
\text { S }\end{array}$ & Sex & $\begin{array}{l}\text { Percent } \\
\text { S }\end{array}$ & Sex & $\begin{array}{l}\text { Percent } \\
\text { S }\end{array}$ \\
\hline Male & 34 & Male & 52.3 & Male & 41.3 \\
\hline Female & 66 & Female & 47.7 & Female & 58.7 \\
\hline $\begin{array}{l}\text { Total } \\
\text { responde } \\
\text { nt }\end{array}$ & 435 & $\begin{array}{l}\text { Total } \\
\text { responde } \\
\text { nt }\end{array}$ & 365 & $\begin{array}{l}\text { Total } \\
\text { responde } \\
\text { nt }\end{array}$ & 320 \\
\hline
\end{tabular}

Table 2 illustrates the formulated demographic analysis of respondents from 2014 to 2016. The respondents consist of 435 Muslim students for the year 2014, 365 students for the year 2015 and a total of 320 students for the year 2016. The descriptive analysis of the respondents' profile shown in this section only refers to the gender based instrument granted. The analysis indicates that 34 percent of the respondents were males and 66 percent were females in 2014. In 2015, 52.2 percent were males and 47.7 percent were females while in 2016, 41.3 percent were males and 58.7 percent were females. Table 3 demonstrates the value of the percentage when interpreted. 
An Investigation Of An Academic Dishonesty Among Higher Education Students

Table 3: Percentage interpretation

\begin{tabular}{cc}
\hline Percentage & Interpretation \\
\hline $1-34$ & Low \\
$35-64$ & Moderate \\
$65-100$ & High \\
\hline
\end{tabular}


Table 4: Finding analysis (comparison from 2014 to 2016)

\begin{tabular}{|c|c|c|c|c|c|c|c|c|c|c|c|c|}
\hline \multirow{3}{*}{$\begin{array}{c}\text { Year } \\
\text { Item no }\end{array}$} & \multicolumn{12}{|c|}{ Frequencies } \\
\hline & \multicolumn{4}{|c|}{2014} & \multicolumn{4}{|c|}{2015} & \multicolumn{4}{|c|}{2016} \\
\hline & Never & Once & $\begin{array}{c}\text { More } \\
\text { than } \\
\text { one }\end{array}$ & $\begin{array}{l}\text { Many } \\
\text { times }\end{array}$ & Never & Once & $\begin{array}{c}\text { More } \\
\text { than } \\
\text { one }\end{array}$ & $\begin{array}{l}\text { Many } \\
\text { times }\end{array}$ & Never & Once & $\begin{array}{l}\text { More } \\
\text { than } \\
\text { one }\end{array}$ & $\begin{array}{l}\text { Many } \\
\text { times }\end{array}$ \\
\hline 1 & $58 \%$ & $35 \%$ & $5 \%$ & $2 \%$ & $62 \%$ & $30 \%$ & $6 \%$ & $2 \%$ & $56 \%$ & $38 \%$ & $3 \%$ & $3 \%$ \\
\hline 2 & $75 \%$ & $16 \%$ & $4 \%$ & $0 \%$ & $68 \%$ & $25 \%$ & $5 \%$ & $2 \%$ & $62 \%$ & $30 \%$ & $6 \%$ & $2 \%$ \\
\hline 3 & $38 \%$ & $16 \%$ & $40 \%$ & $6 \%$ & $29 \%$ & $18 \%$ & $46 \%$ & $7 \%$ & $42 \%$ & $23 \%$ & $35 \%$ & $0 \%$ \\
\hline 4 & $48 \%$ & $28 \%$ & $18 \%$ & $6 \%$ & $44 \%$ & $31 \%$ & $19 \%$ & $6 \%$ & $39 \%$ & $34 \%$ & $23 \%$ & $4 \%$ \\
\hline 5 & $58 \%$ & $21 \%$ & $17 \%$ & $6 \%$ & $47 \%$ & $27 \%$ & $20 \%$ & $6 \%$ & $58 \%$ & $21 \%$ & $17 \%$ & $6 \%$ \\
\hline 6 & $40 \%$ & $30 \%$ & $20 \%$ & $10 \%$ & $36 \%$ & $31 \%$ & $23 \%$ & $10 \%$ & $31 \%$ & $36 \%$ & $25 \%$ & $8 \%$ \\
\hline 7 & $61 \%$ & $35 \%$ & $4 \%$ & $0 \%$ & $58 \%$ & $38 \%$ & $3 \%$ & $1 \%$ & $63 \%$ & $35 \%$ & $2 \%$ & $0 \%$ \\
\hline 8 & $65 \%$ & $23 \%$ & $12 \%$ & $0 \%$ & $61 \%$ & $31 \%$ & $7 \%$ & $1 \%$ & $64 \%$ & $28 \%$ & $7 \%$ & $1 \%$ \\
\hline 9 & $66 \%$ & $22 \%$ & $10 \%$ & $2 \%$ & $71 \%$ & $18 \%$ & $8 \%$ & $3 \%$ & $77 \%$ & $18 \%$ & $5 \%$ & $0 \%$ \\
\hline 10 & $18 \%$ & $23 \%$ & $56 \%$ & $3 \%$ & $16 \%$ & $38 \%$ & $43 \%$ & $3 \%$ & $17 \%$ & $32 \%$ & $48 \%$ & $3 \%$ \\
\hline \multicolumn{13}{|l|}{ Total } \\
\hline $\begin{array}{l}\text { Overall pe } \\
\text { academic }\end{array}$ & $\begin{array}{l}\text { age of } \\
\text { nesty }\end{array}$ & & $47 \%$ & & & & & & & & & \\
\hline
\end{tabular}


An Investigation Of An Academic Dishonesty Among Higher Education Students

Table 5: Questionnaire items

\begin{tabular}{|l|l|l|l|}
\hline $\begin{array}{c}\text { Item } \\
\text { No }\end{array}$ & \multicolumn{1}{|c|}{ Question } & $\begin{array}{c}\text { Item } \\
\text { No }\end{array}$ & \multicolumn{1}{|c|}{ Question } \\
\hline 1 & Turned in the work you copied from other students & 6 & $\begin{array}{l}\text { Copied a few sentences from a book, magazine, or other } \\
\text { source without citing them }\end{array}$ \\
\hline 2 & $\begin{array}{l}\text { Turned in an assignment on which your parents did most } \\
\text { of the work }\end{array}$ & 7 & $\begin{array}{l}\text { Used unpermited crib notes (or cheat sheets) during a test } \\
\text { or exam }\end{array}$ \\
\hline 3 & $\begin{array}{l}\text { Got questions or answer from someone who had already } \\
\text { taken the test }\end{array}$ & 8 & Copied from other students during a test or exam \\
\hline 4 & Let other students copy an assignment & 9 & Helped someone else cheat on a test \\
\hline 5 & $\begin{array}{l}\text { Worked on an assignment with another student when } \\
\text { lecturers asked for individual work }\end{array}$ & 10 & $\begin{array}{l}\text { Copied a few sentences from a site on internet without } \\
\text { citing them }\end{array}$ \\
\hline
\end{tabular}

Adapted from: Don Mc Cabe (2011). 
Based on Table 3, the interpretation indicates the perception level of the Muslim students for 2014, 2015 and 2016 against the practice of academic dishonesty to be at the moderate level - 47 percent in 2014; 51 percent in 2015 and 49 percent in 2016. This result implies that the level of student academic dishonesty is still at a moderate level although it exists widely among students in Malaysia.

The frequency of the academic dishonesty existing among Muslim students was noted to be at a good level. Most of the students stated "never" on most items and the total value was 53 percent in 2014, the figure was 49 percent in 2015 and 51 percent in 2016. Following this was their response to the same statement of "once" which was indicated by 25 percent in 2014, about 29 percent in 2015 and 30 percent in 2016. The response of "more than one" showed that the total consent was 19 percent in 2014, about 18 percent in 2015 and 17 percent in 2016. As for the response of "many times", the responses showed that the frequency was four (4) percent for 2014 and 2015 and three (3) for 2016.

Table 6: The highest percentage of academic dishonesty

\begin{tabular}{cccc}
\hline Item no & $\mathbf{2 0 1 4}$ & $\mathbf{2 0 1 5}$ & $\mathbf{2 0 1 6}$ \\
\hline 10 & $82 \%$ & $84 \%$ & $83 \%$ \\
3 & $62 \%$ & $71 \%$ & $58 \%$ \\
4 & $52 \%$ & $56 \%$ & $61 \%$ \\
6 & $60 \%$ & $64 \%$ & $69 \%$ \\
\hline
\end{tabular}

Overall, the findings indicate that the occurrence of academic dishonesty was at a moderately high level (see table 4) but based on Table 6, aspects of academic dishonesty that have become the highest is item 10, "copied a few sentences from a site on the internet without citing them". The responses recorded were 83 percent for 2014, about 84 percent for 2015 and 83 percent for 2016. In addition, aspects which carried the highest frequency was "got a question or an answer from someone who had already taken the test" which recorded 62 percent for 2014, about 71 percent for 2015 and 58 percent for 2016. The item "let another copy students an assignment" seemed to carry a total of 52 percent for 2014, about 56 percent for 2015 and 61 percent for 2016. In contrast, the responses 
which were at the highest note was "copied a few sentences from a book, magazine, or other source without citing them" which carried a total of 60 percent for 2014, about 64 percent for 2015 and 69 percent for 2016. As a conclusion, the percentage of academic dishonesty among Malaysian Muslim students was seen to be increasing in 2015 and 2016, when compared to the previous year. The findings also showed that this phenomenon of academic dishonesty was still prevalent among students and it certainly needs to be addressed and examined comprehensively so that it does not continue to be on the rising trend.

\section{Discussion and conclusion}

This study has demonstrated a robust finding which showed that most aspects of academic dishonesty that occurred among higher education students was on a rising trend. Among the aspects noted to be high was the factor related to the use of the Internet and online access. The practice of copying from the Internet, not making the right references, taking material from others without giving credit and recognition to the original author are the big issues involving academic dishonesty among these students. Such problems could have emerged due to several factors, for instance, easy access to the Internet which enables students to take the easy way out to complete assignments and tasks which involve academic information and evidence. In the modern world which is booming with technology, IT (information technology) such as the Internet, social networking sites and so on are a threat to the academic world (Peled, Eshet, Grinautski, 2013). The finding of this study matches the study conducted by Muir (2006); Lau, Caracciolo, Roddenberry and Scroggins (2012); Peled et al. (2013) which found that in 1999 as much as 10 percent of students were copying materials through the "cut and paste" method but by 2005 , about 40 percent of the students were using the same method to solve their project papers. The finding of this study also also consistent with the earlier findings of Stogner, Miller and Marcum (2014); Thrushell, Byrne and Hassan (2013) which found that among the factors that contribute to the occurrence of academic dishonesty are the accessibility of the Internet and IT. Stoner et al. (2014) reported that almost two out of 
every five students had engaged at least one form of electronic cheating in their studies.

Similar to the above studies, the outcome of the current study further confirms the findings of Harris, (2011) which had shown that some important factors contribute to academic dishonesty within the scope of education in Malaysia. Here, it was observed that the contributing factor was the institution, Internet access and selfattitude. Part of this was endorsed by Balazs and Laszlo (2013) who reported that technology affects academic dishonesty among students. Linking this together, it can thus be seen that modern technology such as the Internet, digital resources and social media not only facilitate communication and access to material science and knowledge, but also simplifies the process of plagiarism. Stoner et al. (2014) said that plagiarism involves nearly 40 percent of students utilizing the internet in most cases. The high rate thus suggests that technological factors will dominate academic dishonesty in the near future if no initiative is taken to curb this from happening.

Another factor that was noted to be underlying this behavior can be traced to the attitude and moral integrity of the students themselves. If the attitude, moral integrity and value that exist within the students are good and intact, such problems involving academic dishonesty will not occur. Further to that is the pressure and constraints placed on the tasks and learning coursework that students are expected to accomplish as their desire to acquire higher grades may propel them towards academic dishonesty. Granitz and Loewy (2007) also observed that pressure to fulfill tasks and assignments can intensify students' attitude towards committing misconduct such as academic dishonesty. Meanwhile, Grover and Hui (1994) and McCabe (1992) also found that the situation could push students to cheat. Hence, among the important principles that should be taken care by individuals is self-regulation and ethical values. If students possess basic moral values, strong ethical beliefs and a stable control over their own desires, their ultimate action will lead to better behaviours. Trevino and Youngblood (1990) insist that misconduct such as plagiarism, cheating and other misbehaviours are influenced by the individual's internal-interaction situation and person-situation interactions. Specifically, the tendency of individuals to behave badly depends on two factors, namely the 
character of the environment and the character of the individual (Weaver, Trevino \& Cochran, 1999). Previous studies have revealed that both these factors, whether the individual surroundings and internal factors, can affect individual actions (Gino \& Margolis, 2011). The findings of the current study showed that many individual internal factors had provoked students into academic dishonesty. Therefore, these are necessary aspects of the development of internal values, moral beliefs and ethical values which should be taken seriously when addressing the issue of academic dishonesty.

The finding of this study, as a whole, has some specific limitations. The study involved only public universities where students from private universities were excluded. This indirectly limits the generalization of the overall process. Future researchers should include private universities and further expand the number of respondents by increasing the number of universities involved. Despite its shortcomings, the findings are able to give a clear picture of the issue of academic dishonesty among Muslim students. This indirectly supports the finding of Moten (2014) which states that the issue of academic dishonesty among Muslim students is high and significant.

In addition, future researchers could also explore the relationship between gender and academic dishonesty. Many researchers have conducted studies and found that gender factors play a big role in this issue. Watson and Suttile (2010) found that females were more likely to commit misbehaviors than males. Likewise, Burkowski and Ugras (1998) also found that women were more unethical than men. Both findings are consistent with the findings of Ruegger and King (1992) which state that gender is the catalyst to the formation of individual behavior, whether good or not. As such, it warrants future researchers to study the correlation between gender and academic dishonesty among Muslim students.

In summary, some important points need to be appropriately addressed by several authorities.

1. There is no denying that the internet has become a necessity in today's lifestyles. It not only helps to simplify and diversify its 
sources of reference and learning, it also affects the integrity of academia. Based on the findings, it appears that most of the problems involving plagiarism and academic dishonesty are eased by the accessibility of the Internet and online resources. Therefore, proactive action needs to be taken to curb this problem from further damaging academic institutions. Stoner et al. (2013) had proposed that educators create a unique assignment which can reduce the likelihood of students plagiarizing or purchasing online materials. It appears that educators may also need to create an assignment that differs from lecture materials which can enable students to incorporate lecture materials and their local knowledge into their responses.

2. Ethical and moral development: These two aspects are noteworthy because students are the future generation who will be educating the forthcoming generation. Ethical values and good manners should be fostered among individuals so as to inculcate strong ethical values, high integrity and relevance. Prior research had proposed that if the development of ethical values is done well and consistently, misconduct can be avoided. For example, through various trainings and treatments, an individual will be able to increase the level of awareness of his/her moral and ethical values (Brendal, Kolbert \& Foster, 2002; Stogner et al. 2013). The suppression of moral values, ethics and integrity within the individuals are important issues to be discussed. Educators can play a role by providing a constant reminder on this and by making an emphasis on the possible offences caused by students when committing academic dishonesty as these can damage their reputation in the future. 


\section{References}

Arief Salleh Rosman, Ahmad Mahyuddin Hassan, Azmi Shah Suratman, M. Nasir Ripin \& Nurazmallail Marni. (2008). Persepsi Pelajar Universiti Teknologi Malaysia terhadap Plagiarisme, Jurnal Teknologi UTM, 48 (E), pp 1-14

Auer, N. \& Krupar, E.M. (2001). Mouse clicks plagiarism: The role of technology in plagiarism and the librarian's role in combating it. Library Trends, 49(3)

Ballentine, J.A, Larres, P.M, Mulgrew, M. (2014). Determinants of Academic Cheating behaviour: The future for Accountancy in Ireland. Accounting Forum, 38 (2014) 55-66.

Baird, J. S. (1980). Current trends in college cheating. Psychology in the Schools, 17(4), 515-522.

Beck, V. (2014). Testing a Model to predict online cheating-Much ado about nothing. Active Learning in Higher education, 15(1), 65-75.

Brendel, J. M., Kolbert, J. B., \& Foster, V. A. (2002). Promoting student cognitive development. Journal of Adult Development, 9(3), 217-227.

Briggs, K., Workman, J.P., York, A.S., (2013). Collaborating to cheat: A Game Theoretic exploration of Academic Dishonesty in Teams. Academy of Management Learning \& educations, Vol 12(1), 4-17.

Burton, J.H., Talpade, S., Haynes, J. (2011) Religiosity and testtaking ethics among business student. Journal of the academic and business ethics. 4. 1-8.

Borkowski, S. C., \& Ugras, K. J. (1998). Business students and ethics: A meta-analysis. Journal of Business Ethics, 17, 1117-1127.

Carmines, E. G., and R. A. Zeller. (1979). Reliability and validity assessment. In Quantitative applications in the social science series Newbury Park, CA: Sage Publications.

Chua Yan Piaw. (2006). Kaedah dan statistik penyelidikan: Asas Statistik penyelidikan buku 2. Kuala Lumpur: McGrawHill. 
Diekhoff, G.M., LaBeff, E.E., Shinohara, K. \& Ysukawa, K.(2009). Collegge Cheating in Japan and the United States. Research in Higher Educations. 40(3), 343-353.

Elliot, J., Deal, J., \& Hendryx, M. (2014). Exposing academic dishonesty: prevalence and correlates at a small,Midwestern liberal-arts school. Journal of Academic and Business Ethics, Volume 9, 1-18.

Galloway, M.K. (2012). Cheating in Advantaged High Schools: Prevalence, Justifications and Possibilities for Change. Ethics and Behaviour, 22(5), 378-399. Doi:10.1080/10508422.2012.679143.

Gino, F., \& Margolis, J. D. (2011). Bringing ethics into focus: How regulatory focus and risk preferences influence (Un)ethical behavior. Organizational Behavior and Human Decision Processes, 115(2), 145-156.

Granitz, N., \& Loewy, D. (2007). Applying ethical theories:

Interpreting and responding to student plagiarism. Journal of Business Ethics, 72(3), 293-306.

Hair, J.F., Babin, B., Money, A.H., \& Samouel, P.(2003). Essentials of Business Research Method. USA: John Wiley \& Sons.

Hairulliza Mohamad Judi., Syahanim Mohd Salleh., Norijah Hussin, \& Sufian Idris. (2012). Pengawasan aktiviti untuk mencegah plagiat pengaturcaraan. Asia-Pacific Journal of Information Technology and Multimedia, 1 (1). pp. 48-57.

Harding, T.S., Carpenter, D.D., Finelli, C.J. (2004). Does Academic Dishonesty relate to unethical behaviour in professional practice? An exploratory study. Science and Engineering Ethics, 10, 311-324.

Jones, D.R.L.(2011). Acdemic dishonesty: Are more student cheating? Business communications Quarterly. 74. 141-150.

Jurdi. H, Hage, H.S, \&.Chow, P.H.(2011). Academic Dishonesty in the Canadian Classroom: Behaviour of a sample of University Student. Canadian Jurnl of Higher Education. Vol 41, (3), 1-35.

Kerlinger, F. N. (1986). Foundations of behavioral research $\left(3^{\text {rd }}\right.$ Ed.). Fort Worth, TX: Holt, Rinehart and Winston 
Koul, R. (2012). Multiple motivational goals, values, and willingness to cheat. International Journal of Education Research, 56(2012), 1-9. Doi: org/10.106/j.ijer.2012.10.002.

Lau, L.K., Caracciolo, B., Roddensberry., \& Scroggins, A. (2012). Collegge Students perceptions of Ethics. Journal of Academic and Business Ethics, 5, 1-3.

Lin, C. H. S., \& Wen, L. Y. M. (2007). Academic dishonesty in higher education: A nationwide study in Taiwan. Higher Education, 54(1), 85-97.

Mahmoud Poorian, Mohammad Javad Nekooei \& Yusof bin Boon. (2013). Academic Cheating In Higher Education The Effect of a Student Developtment Approach A study At Universiti Teknologi Malaysia. IOSR Journal of Research \& Method in Higher Education. Volume 1, Issue 6. pp 40-43.

Ma, H., G. Wan, and E. Lu. (2008). Digital cheating and plagiarism in schools. Theory into Practice 47: 197-203.

Mc Cabe, D.L., Trevino, L.K., \& Butterfield, K.D.(2002). Honor Codes and other contextual influence on academic integrity: A replication and extension to modified honor settings. Research in Higher Educations, 43, 357-378.

McCabe, D. L. (1992). The Influence of Situational Ethics on Cheating Among College Students. Sociological Inquiry, 62(3), 365-374. http://doi.org/10.1111/j.1475682X.1992.tb00287.x

McCabe, D.L., (1997). Individual and contextual influences on academic dishonesty, Research in Higher Educations, 38 (3), 379-396

McCabe, D.L., (2005). Cheating among College and University Student: A North American perspective, International Journal for Educational Integrity, 1 (1).

Mei Wah.M. Williams \& Matthew Neils Willliams.(2012). Academic dishonesty, self-control and General Criminality: Prospective and Retrospective Study Of Academic Dishonesty in a New Zealand university. Ethic and Behaviour, 22(2), 89-112 
Moten, A.R. (2014). Academic dishonesty and Misconduct: Curbing plagiarism in the Muslim world. Intellectual Discourse, 22(2), 168-189

Nunnally, J.C. (1978), Psychometric Theory (2 ${ }^{\text {nd }}$. Ed.), McGrawHill, New York.

Nunally, J. C. \& Bernstein, I. H. (1994). Psychometric Theory: Third edition. New York: McGraw Hill.

Nursiha Saidin, Nurliyana Isa.(2013). Investigating Academic Dishonesty among Language Teacher Trainee: The Why and How of Cheating. Procedia-Social and Behavioral Sciences. 90, 522-529

Peled, Y., Eshet, Y. \& Grinautski, K.(2013). Perceptions Regarding the Serious of Academic Dishonesty amongst Student- A comparison between Face-to Face and Online Courses. Proceeding of the Chais Conference on Instructional Technologies research, 69-74.

Ruegger, D., \& King, E. W. (1992). A study of the effect of age and gender upon student business ethics. Journal of Business Ethics, 11(3), 179-186.

Saveri Karim \& Ebrahimi Ghavam. (2011). The Relationship between Self Control, self-effectiveness, Academic Performance and Tendency toward Academic Cheating: A Case Report of University Survey in Iran. Malaysina Journal of Distance Education, 13(2), pp 1-8.

Simkin, M., \& McLeod, A. (2010). Why do college students cheat? Journal of Business Ethics. 94(3).

Sukarmin (2010) Hubungan Tingkah Laku Kepimpinan Pengajaran

Guru Besar dengan Keafiatan Sekolah, Komitmen Organisasi, Efikasi dan Kepuasan Guru Sekolah. PhD thesis, Universiti Utara Malaysia

Sekaran, U., \& Bougie, R. (2010). Research Methods for Business. New York: John Wiley \& Sons Ltd

Trevino, L. K., \& Youngblood, S. a. (1990). Bad apples in bad barrels: A causal analysis of ethical decision-making behavior. Journal of Applied Psychology, 75(4), 378-385 
Trevino, L. K. (1986). Ethical Decision Making in Organizations: A

Person-Situation Interactionist Model. Academy of Management Review, 11(3), 601-617.

Spinellis, D.P, Zaharias, A. Vrechopoulus, (2007). Coping with plagiarism and grading load: randomised programming assignment and reflectives grading. Computer Applications in Engineering Educations, 15: pp 115-123

Weaver, G. R., Trevi??o, L. K., \& Cochran, P. L. (1999).

Integrated and decoupled corporate social performance:

Management commitments, external pressures, and corporate ethics practices. Academy of Management Journal, 42(5), 539-552.

Williams, K.M., Nathanson, C., \& Paulhus, D.(2010). Identifying and profiling scholastic cheaters: Their personality, cognitive ability and motivation. Journal of experimental psychology:applied, 16, 293-307.

Whitley, B.E., Jr. (1998). Factors associated with cheating among college students: A review. Research in Higher Education, 39(3), 235-274. 